\title{
Issues of Refugees and Displaced Persons in Nigeria
}

\author{
Oduwole Tajudeen A. \\ Department of Sociology, Houdegbe North American University, Republic of Benin
}

Fadeyi Adebayo O.

Department of Sociology, Lagos State University, Ojo, Lagos State, Nigeria

Accepted: December 23, 2012 Published: January 27, 2013

Doi:10.5296/jsr.v4i1.3156 URL: http://dx.doi.org/10.5296/jsr.v4i1.3156

\begin{abstract}
This paper evaluates the state of internally displaced persons in Nigeria. Paramount objective of the paper anchors on examining the quantum leap and systemic loss of lives and properties in the country in recent times. The study elicits its information gathering using an ethnographic approach, a semi-unstructured interview was purposefully conducted on some of the survivors of bomb attack on UN building at Abuja who are resident of Lagos, victims of displaced persons that experienced devastating floods that destroyed their homes and properties, relations of some of slain youth corps members that equally reside in Lagos were interviewed. The study heavily relies on authoritative and valid secondary sources of data National dailies (Nigeria Tabloids), journals, articles etc. on the desk type of research. The major findings of the study revealed neglects on the part of the State apparatus (government) in ensuring better, effective and functional policies. Its magnitude is capable of threatening national cohesion of the country and endangering high rate of internally displaced persons across the country. The study concludes that given the magnitude and complexity of crises of internal displacement, these are inimical toward the discourse "Development". This affects the country from achieving Millennium Development Goals - goal number eight (8): rights to safety of lives and properties as equally enshrined in other international treaties - choices to healthy, creative life and to enjoy a decent standard of living, freedom, dignity and self-respect and the respect of others. This argument is adjudged valid, given the empirical instance of poverty, inequality, unprecedented levels of bomb blast across the country and above all displacement vis-à-vis what development connotes.
\end{abstract}

Keywords: Refugees, Displaced person, Internally Displaced Persons, Sustainable-Development, Social-welfare

\section{Introduction}

The plight of displaced persons has in recent years become a formidable problem of global significance and implications (Ladan, 2001). The total number of displaced persons is currently estimated around fifty million worldwide, with the majority of these people in 
Africa and Asia. Displacement across the country is a common result of both communal violence and internal armed conflicts. While some of the conflicts appear to be caused by religious or ethnic differences, benefits of a political, social and economic nature are generally behind the violence in the country with endemic poverty, low levels of education and a huge and alienated youth population. Nigeria regularly experiences displacement as a consequence of natural disasters such as flooding or soil erosion. Nigeria has been affected by recurrent internal conflicts and generalized violence since the end of military rule and the return of democracy in 1999. The systematic and overlapping patterns of inequality in the country have been described as "breeding grounds" for conflict (Okpeh, 2008; CRISE, 2007).

As a result, the country is faced with the ongoing challenge of responding to fluctuating but always sizeable internally displaced population. Nigeria is made up of a web of ethnic, linguistics and religious, social groupings. Conflicts have been triggered by disputes over access to land, kingship, cultural, residual citizenship and broader questions of identity. Identities have been particularly important in the shaping of both the political and social arena in Nigeria both during colonial and post-colonial times. Under British colonial rule, religious, ethnic and regional differences were given prominence, which eventually exacerbated divisions between Muslims and Christians, Northerners and Southerners, and Hausa - Fulani, Yoruba and Igbo groups (Okpanchi, 2010). Such differences, particularly between people considered indigenous to an area and those regarded as settlers, became instrumental after independence in the manipulation of identities for political ends (Jega, 2000).

This paper examines internally displaced persons under international law conceptually, and their implications for sustainable development in Nigeria. The following section shall examine the common causes of displacement, while subsequent portions analyze the legal protection available to displaced persons with special references to internal human rights law and to draw conclusions with some viable options for governments and other key stake holders.

\section{Displaced Persons}

Displaced persons under international law are persons or groups of persons who have been forced or obligated to flee or to have cause to leave their homes or place of habitual residence in particular, as a result of or in order to avoid the effect of armed conflict, situations of generalized violence, violations of human rights or natural or human-made disasters, and they must have either remain within their own national borders (as internally displaced persons) or they must have crossed an internationally recognized state border (as refugees), (Ladan, 2006). Hence displaced persons are of two categories: Refugees and Internally Displaced Persons. (IDPs).

The convention relating to the status of refugees (CRSR) of 1951 defines the term "refugee" as applying to any person who 
“...as a result of events occurring before $1^{\text {st }}$ January 1951 and owing to well founded fear of being persecuted for reasons of race, religion, nationality, membership of a particular social group or political opinion is outside the country of his (or her) nationality and is unable, or owing to such fear, is willing to avail himself (or herself) of the protection of that country; or who, not having a nationality and being made outside the country of his (or her) former habitual residence as a result of such events, is unable, or owing to such fear, is unwilling to return to it...” (Ibid, pp. $252-3$ ).

In comparison to the CRSR of 1951, the OAU convention (1969) governing the specific aspects of refugee problem in Africa gives a broader definition of the term "refugee", taking account of most of the root causes of the refugee problem. The second paragraph of article 1 of the OAU convention state that:

"the term 'refugee' shall also apply to every person, who, owing to external aggression, occupation, foreign domination or events seriously disturbing public order in either part of the whole of his (or her) country of origin or nationality, is compelled to leave his (or her) place of habitual residence in order to seek refugee in another place outside his (or her) country of origin or nationality".

Under the Cartagena Declaration, the term "refugee" is defined as including "Persons who have fled their countries because their lives, safety or freedom have been threatened by generalized violence, foreign aggression, internal conflicts, massive violations of human rights or other circumstances which have seriously disturbed public order". (UNHCR, 1995).

On the other hand, internally displaced persons (IDPs), as a result of situations of armed conflicts (or the threat thereof) and mass violations of human rights, as well as floods, earthquakes and other natural disasters, the number of people fleeing their homes has increased dramatically over recent years. There are also deep - seated factors underlying this phenomenon of mass displacement. For example, Under-development, poverty, in equal distribution of wealth, unemployment, ethnic tensions, political and economic subjugation of minorities, intolerance, absence of democratic procedures, and many other factors have been cited as causes. Where such people, in fear of persecution, seek refuge in other countries, their interests are protected by the refugee convention of 1951 and the 1967; protocol relating to the statute of refugees. If those persons are victims of armed conflict situations, they are entitled to protection under the Geneva Convention of 1949 and their additional protocols of 1977. In general, human rights law offers protection to all persons without any adverse distinction. However, where such people and displaced within their own country, specific problems as the rights and protection arise (Deng, 1994).

Under the following working definition of "Internally Displaced persons" (IDPs), which was developed by the special Rapporteur on IDPs as there is at present no specific international 
legislation devoted to that issue, displaced persons are deemed as:

"Persons or groups of persons who have been forced to flee their homes or places of habitual residence suddenly or unexpectedly as a result of armed conflict, internal strife, systematic violations of human rights or natural or man-made disasters, who have not crossed an internationally recognized state border". (OCHA, 2003; UN, 2004).

In addition to the 9.2million refugees worldwide, there are more than twice as many people who have been uprooted from their homes but whom unlike refugees, remain within the borders of their own countries and are called internally displaced persons. Around the world, some 23.7 million women, men and children have been internally displaced by conflict, communal violence, and internal strife (Kalin, 2006). Many millions more have been displaced by natural disasters and developmental project. Africa bears a disproportionate and truly staggering toll of the global problem of internal displacement. Of those internally displaced by conflict and communal violence, more than half, an estimated 12.1million persons, are in Africa, with over one million in the fifteen ECOWAS states; and about half a million IDPs in Nigeria alone. (Onijala, 2006). Recently, the flooding that occurred in some states in Nigeria; year 2012, the (NEMA, 2012) put the figure of those that lost their lives at three hundred and sixty two (362) while over two million people across the country were displaced.

\section{Causes Of Displacement In Nigeria}

According to a strategic conflict assessment carried out by the Institute for peace and conflict resolution in 2002, the return to democracy and the competition for the new political opportunities had led to increased violence. Local competition for resources has often been aggravated by "inter-elite" rivalries over privileges such as political and public service appointments, oversight of projects and admission into schools (IPCR, 2002). Additionally, the specific tripodal ethnic structure (with the Hausa, Yoruba and the Igbo constituting the three major groups) in Nigeria is particularly unstable and often in conflict. The interplay between the tripodal structure and communal identities has been aggravated overtime by systematic patterns of inequalities.

In particular, the Niger Delta, Rivers, Bayelsa and Delta states, considered the core of the southern Niger Delta region, have been the scene of violent competition for land, political and oil wealth. Following the economic decline of the 1990s, the region became vulnerable to ethnic polarization, with different groups resorting to different means to fight for their rights (Irobi, 2010).

In 2005, the Movement for the Emancipation of the Niger Delta (MEND) was created through the merger of different armed groups. In May 2009, thousands of people were displaced in one of the clashes between government forces and MEND. The Joint Task 
Force (JTF) charged with restoring order in the Niger Delta launched operation 'Restore Hope' in an effort to uproot militant groups. The JTF launched land and air armed strikes around the city of Warri in Delta State, and later extended its offensive to neighboring Rivers State (Reuters, 2009). Number of Internally Displaced Persons (IDPs) reported have varied, from 1,000 people sheltering in a school and hospital in the local capital in Ogbe Ijoh to up to 10,000 residents believed to have fled and unable to return home (IRIN, 2009; Al, 2009). However, a government amnesty programme, which includes a comprehensive programme to disarm, demobilize and rehabilitate hitherto militants, has been credited for a drop in large scale violence in the Delta in 2010 (IRIN, 2010).

The "middle belt", which runs across Nigeria, is the area with the highest concentration of minority ethnic groups. It comprises Taraba, Adamawa, Plateau, Nassarawa, Benue, Kogi states as well as Southern Zaria, and Southern Kaduna (Action Aid, 2008). All these areas have witnessed intra-ethnic or inter-ethnic conflicts that have spread across different states. Researchers have pointed to a "crisis of citizenship" in which "different attitudes to citizenship contribute to political conflicts". (Idowu, 1999) articulated around the "shelter native" identity, with conflicts fuelled by feelings of exclusion and struggles for recognition (Action Aid, 2008). For instance, clashes between security forces and an Islamic group called Boko Haram led to death and displacement of many people. Though depicted as an ethno religious conflict, analysts read the violence as the result of weak or inefficient governance and widespread poverty. Also, linked to violence that often displaced people from their abode; the bloody violence being perpetrated by the members of the national union of road transport workers and post-election violence in 2011, that claimed the lives of ten (10) National Youth Corpers posted to serve their father land in the Northern states of Nigeria and displaced others from their primary place of assigned scheme.

Closely linked to this is the issue of natural disasters such as flooding or soil erosion. In conflict - affected states, natural disaster have complicated displacement and return patterns and have in some cases been difficult to distinguish between people displaced by conflict and other causes.

In 2010, the Nigerian government asked the help of the United Nations to carry out a profiling exercise that would provide a clearer picture of The number and situations of IDPs in the country (UN, 2010).

\section{Legal Protection Of Displaced Persons}

There are no official IDPs camps of long lasting nature in the country. Temporary shelter is normally provided in army or police barracks, schools or hospitals, but they serve as IDPs camps only for a limited period. The vast majority of displaced people in Nigeria reportedly seek refuge with family, friends, or host communities in areas where their ethnic or religious group is in the majority (Je'adayibe, 2008). Many appear to return to their homes or resettle near their home areas soon after the violence which forced them to leave have subsided, but 
an unknown number also resettle in other areas of the country.

In international law, refugees are granted a special legal status because they have lost the protection of their own country and, therefore, are in need of international protection not necessary for those who do not cross international borders.

Internally displaced persons do not need such a substitute or a surrogate protection. Rather as human beings who are in a situation of vulnerability, they are entitled to the enjoyment of all relevant guarantees of human rights and humanitarian law, including those that are of special importance to them. This does not rule out the possibility of administrative measure such as registration on the domestic levels to identify those who are displaced and need special assistance. However, lack of such registration would not deprive IDPs of their entitlements under human rights and humanitarian law (Ladan, 2001).

\section{International Refugee Law}

Article 31, which prohibits penalties on refugees who are in a country unlawfully provides:

"The contracting state shall not impose penalties, on account of their illegal entry or presence, on refugees who, coming directly from a territory where their life or freedom was threatened, in the sense of article 1, enter or are present in their territory without authorization, provided they present themselves without delay to the authorities and show good cause for their illegal entry or presence".

ARTICLE 33, which sets out the fundamental principle of non-refoulment reads:

"No contracting state shall expel or return ('refouler') a refugee in any manner whatsoever to the frontiers of territories where his life or freedom would be threatened on account of his race, religion, nationality, membership of a particular social group or political opinion”.

The remaining articles of the 1951 convention provided numerous rights for refugees in asylum countries, covering such as:

- Non-discrimination (Article 3)

- Freedom of religion (Article 4)

- Right to association (article 15)

- $\quad$ Right to access to the courts (Article 16)

- Right to work (Article 17, 18, and 19)

- Social rights (Article 20, 21, 23 and 24)

- Right to education (Article 22)

- Right to movement (Article 26)

- $\quad$ Right to travel document (Article 28) 
With the most obvious exception of article 28 , many of these provisions only require state to grant the same rights to refugee as are granted to other non-nationals.

\section{The Guiding Principles Of Internal Displacement}

The guiding principles on internal displacement ('Guiding principles') are the first international standards specifically tailored to the needs of IDPs. Based on international humanitarian law, human rights law and refugee law by analogy, the Guiding principles set forth the right of IDPs and explain the obligations of national authorities and non-state actors towards IDPs. They cover all phases of internal displacement: the pre-displacement phase during displacement; and during return or resettlement and re-integration.

The guiding principles begin with an introduction explaining their scope and purpose. In the introduction, internally displaced persons are described as:

Persons or groups or persons who have been forced or obliged to flee or to leave their homes or places of habitual residence. In particular as a result of or in order to avoid the effects of armed conflicts, situations of generalized violence, violations of human rights or natural or human-made disasters, and who have not crossed an internationally recognized border.

This description highlights the two core elements of internal displacement:

1. The coercive or otherwise involuntary character of the movement; and

2. The fact that such movement takes place within national borders. It is also important to note that the list of causes of displacement is not exhaustive. It covers persons who are obliged to leave their home and place of residence because of conflict and large-scale human rights violations as well natural disasters and development projects. In this context, it is important to note that the notion of displacement is neutral in the sense of covering both situations where persons are forced to leave in violation of their rights and instances of evacuations and relocations/resettlements that are involuntary but perfectly legal.

Section 1 sets out general principles relating to the rights of IDPs and the responsibilities of national authorities. Importantly, principles 3 (1) explains that national authorities have the primary duty and responsibility to provide protection and assistance to IDPs within their jurisdiction. In addition, principle (1) stipulate that IDPs are entitled to enjoy in full equality the same rights and freedoms as other persons in their country and shall not be discriminated against because of their displacement. At the same time, the guiding principles acknowledge that certain groups of IDPs - especially unaccompanied minors, expectant mothers, mothers with young children, female heads of household, persons with disabilities and elderly persons - may require specific attention. 
Section II address the issue of protection from displacement and articulates to right not to be arbitrarily displaced. In practice, therefore, states are under an obligation to avoid the displacement of population and in particular to protect against the displacement of groups with a special dependency on, or attachment to, their lands. When displacement is unavoidable, the Guiding Principles specify minimum guarantees to be observed.

The third and most extensive section of the Guiding Principles identifies the full range of civil, political, economic, social and cultural rights that all persons, including IDPs, should enjoy. This includes, for instance, the rights according to principle 11 (2) (a) - to be protected against acts of violence, torture and cruel, inhuman or degrading treatment or punishment as well as the right to be protected against the use of anti - personnel land mines ( Principle 10 $(2)(€)$. Principle 22 (d) specifically identifies the rights of IDPs to vote and to participate in governmental and public affairs, whether or not they are living in camps. Principle 18 relates to the right to an adequate standard of living, including ensuring safe access to essential food, potable water, basic shelter and housing as well as appropriate clothing and essential medical services and sanitation.

The third section also state that special attention should be given to the prevention of contagious and infectious diseases, (including AIDS, among IDPs (Principle 19 (3)).

The fourth section deals with the issue of humanitarian assistance and specifies that when governmental authorities are unable or willing to provide assistance to the displaced, international organization have the right to offer their services, and that consent for them to do so shall not be arbitrarily withheld.

The final section of the Guiding Principles emphasizes the importance of providing IDPs with long-term options, namely voluntary return in safety and dignity or resettlement in another part of the country. It also emphasize the importance of ensuring durable solutions, including the needs to provide IDPs with integration assistance, whether they return or resettle, and to ensure they have equal access to public services. In addition, this section explains the beauty of national authorities to assist IDPs recover the property and possessions they lost upon displacement or, when this is not possible, to assist them in obtaining compensation or another form of just reparation.

Throughout the guiding principles special attention is paid to the protection, assistance and reintegration needs of women and children. These two groups typically comprise the overwhelming majority of displaced populations. They are currently estimated as comprising $70-80 \%$ of the IDP population worldwide. The guiding principles call for the participation of women in the planning and distribution of relief supplies. They require special attention to be paid to the health needs of women, including access to female health care providers and services, and special efforts be made to ensure the full and equal participation of women and girls in educational programmes. They also prohibit sexual violence, stress the need for family reunification, and highlight the right of women to equal access to personal identity and 
other documentation and to have such documentation issued in their own names. Principle 23 recognizes the right to education and states that special efforts must be made to ensure that women and girls enjoy equal and full participation in educational programme in relation to children, principle 13 (2) adds that under no circumstances are children to be recruited or to be required or permitted to take part in hostilities.

Importantly, the guiding principles are being used at the national level in countries affected by internal displacement. Particularly worthy of notes is the development of both natural and natural laws and policies based on principles. In Africa for example, Angola led the way as the first country in the world to incorporate the Guiding Principles into domestic legislation, with the Norms for the Resettlement of displaced populations. Adopted in January 2001 in anticipation of the end of conflict in the country and the possibility of durable solutions for the displaced, the norms set forth minimum standards for the protection and assistance of IDPs during their resettlement. For instance, they affirm that all returns must be voluntary and should occur in conditions of safety. They specify that returning IDPs are to have access to land and should receive seeds and tools.

Further, the Norms provided that rule of law and public infrastructure such as schools must be located in areas of the returnees. In West Africa, Nigeria is in the process of developing a policy on internal displacement, a recent draft of which reveals the comprehensive concern that Nigeria takes to displacement, addressing all its probable causes, including conflict, natural disaster and development projects. In Liberia, the president announced the endorsement of the Guiding principles which have been referenced in domestic law.

Several other government including Burundi, Columbia, Georgia and Uganda, have also expressly referenced the Guiding Principles in their national laws and policies (Annan, 2005)

National human rights institutions, for instance in Uganda and in countries in South Asia and the Americans, are also making use of the Guiding Principles to promote and protect the rights of the internally displaced. Even some non-state actors have begun to refer to the Guiding Principles as a guide for protecting and assisting the internally displaced in their zones of influence. Moreover, around the world, civil society groups have been instrumental in disseminating the Guiding Principles and using them as a basis for advocating for the rights of the internally displaced. IDPs themselves are using the Guiding Principles as an empowerment tool (Annan, 2005).

The normative framework found in the Guiding Principles not only sets out the norms to be observed but also provides a framework for dialogue on IDPs issues, thereby lending support to the development of effective strategies for preventing and effectively responding to internal displacement. A number of countries, including some in West Africa have set up a training workshop to bring together representatives of national and local government, civil society, IDP communities and international agencies have raised awareness and understanding of the Guiding Principles to stimulate the development of national strategies 
and promote their application.

As a sign of their broad use, the Guiding Principles have been translated from English into 40 languages, including French, Portuguese, Hausa, Igbo and Yoruba (Ibid).

\section{A Profile Of Crises That Resulted In Killings And Displacements In Nigeria}

Recently,the Jos crisis alone witnessed over two hundred (200) people killed in six months and others displaced (The Punch, 2011).

The profile of people killed between January - September 2011,is sketched below:

$7^{\text {th }}$ January At least eight people were killed

$8^{\text {th }}$ and $9^{\text {th }} \quad$ Over 60 were killed in different communities

$10^{\text {th }}$ January $\quad 60$ more people were reported killed

$11^{\text {th }}$ January $\quad 31$ people were killed in four villages in Barkin Ladi, Kuru Tasha and Riyom areas.

$29^{\text {th }}$ January Over six people were killed near University of Jos.

$15^{\text {th }}$ February $\quad 30$ people were killed in Jos market and

$22^{\text {nd }}$ February $\quad 18$ people were reportedly killed in Rwang Fang village

$14^{\text {th }}$ March Six people were killed in two separate attacks

$21^{\text {st }}$ March Three persons were killed by an explosion at Nassarawa Gwong

$19^{\text {th }}$ April Seven people were killed in Riyom area

$16^{\text {th }}$ July Seven people were killed in Maza village

$29^{\text {th }}$ August 20 people were killed in renewed attacks

$5^{\text {th }}$ September $\quad 11$ people were killed

$10^{\text {th }}$ September 14 people were killed at Vwang Kogot

Source: The Punch, September 11, 2011 - A Nigerian Tabloid.

In another dimension, floods ravaged Ibadan, South West of Nigeria on the $26^{\text {th }}$ of September, 2011. The Red Cross reported that at least one hundred and two (102) people were killed by the flood, while some 1,500 people remain displaced by the down pour. The water also damaged three bridges in the area, trapping people in their neighborhoods, the official with Nigeria's National Emergency Management Agency reported. The Agency equally reported that some 500,000 people were displaced nationwide by floods in the country in 2011 . 


\section{IInstituthink}

\section{A Cross-Section (Potraits) Of Flood Victims - 2011}

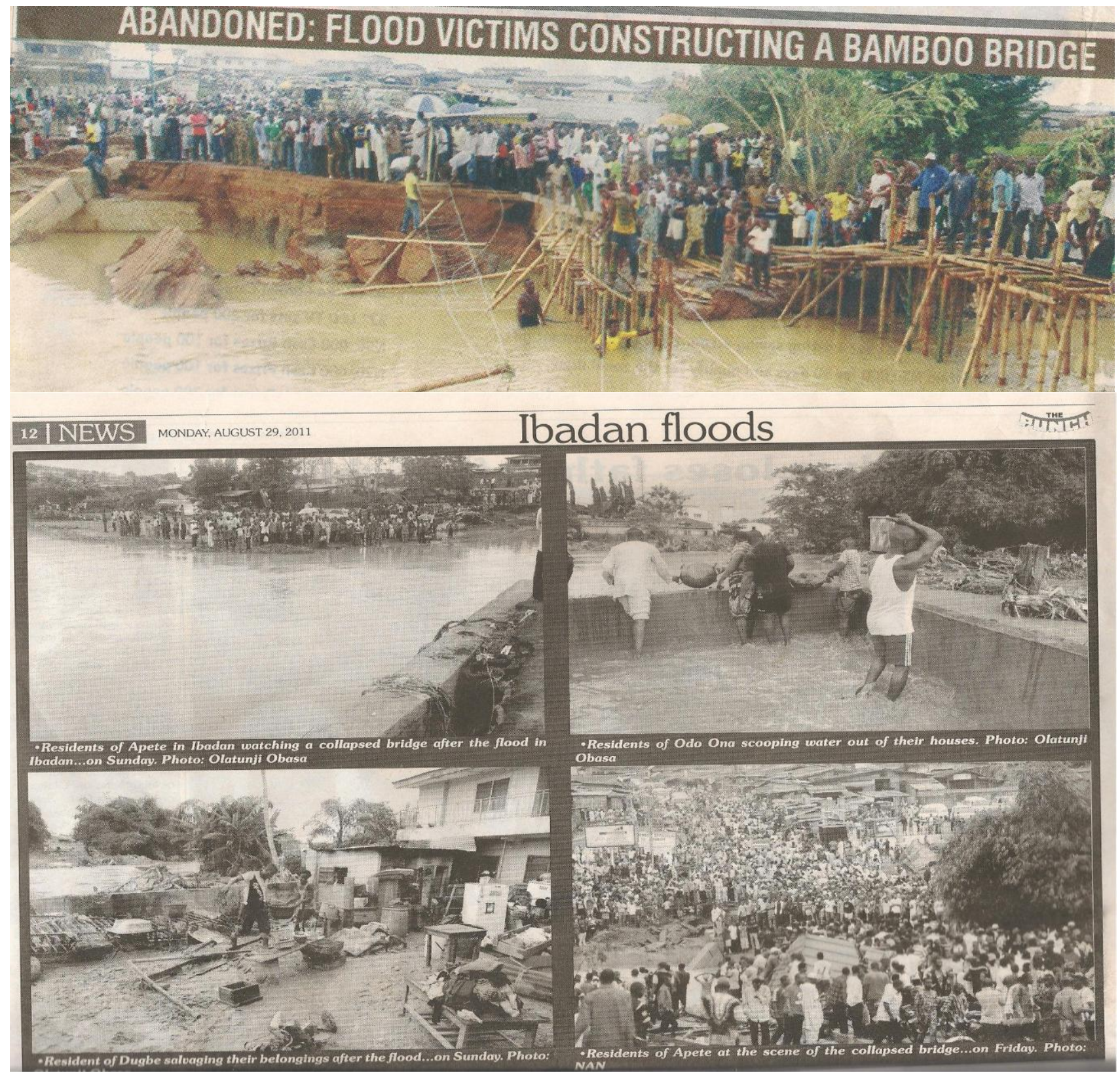




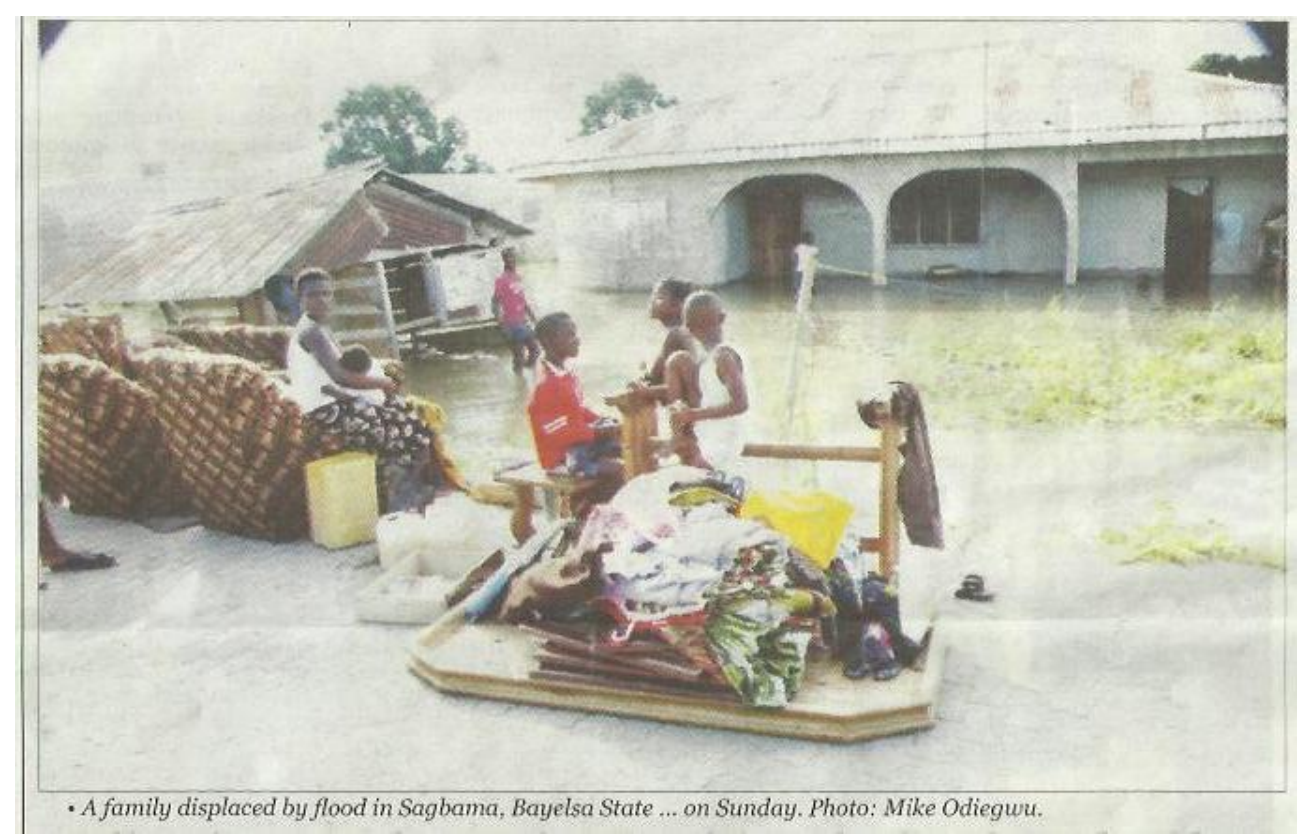

Source: The Punch, Monday, October 8, 2012.

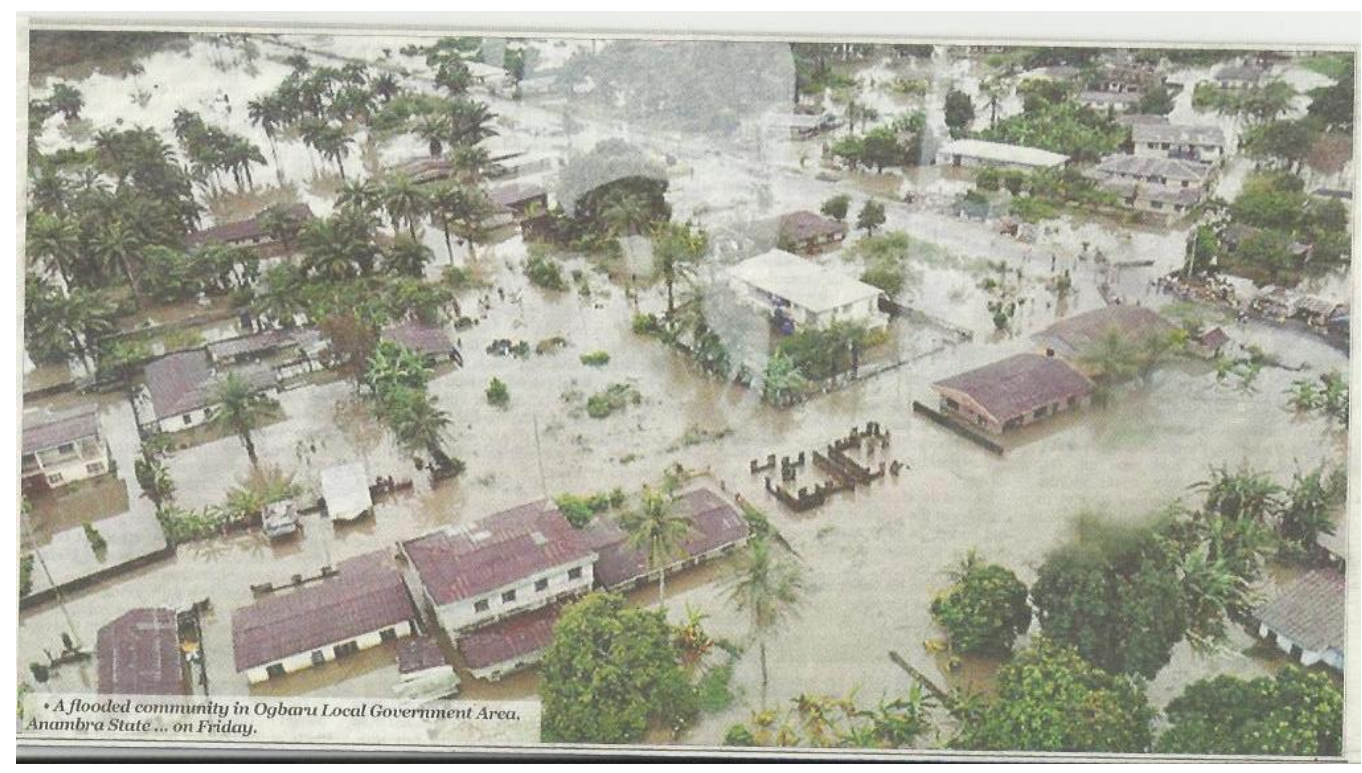

A flooded community in Ogabru Local Government Area, Anambra State Source: The Punch, Monday, October 8, 2012.

The UN bombing perpetrated by Boko Haram sects is another dislocation of people from their work places and even at homes. The suicide bomb attack on the united nation's building in Nigeria's capital, Abuja, on Friday morning, 26 ${ }^{\text {th }}$ August, 2011 left 18 people dead and 


\section{Mll Macrothink}

Journal of Sociological Research

ISSN 1948-5468

2013, Vol. 4, No. 1

several others wounded. This was viewed as the peak of political discoloration of nation co-habitation and national integrity.

\section{Cross-Sectional Of Potraits Of Un Bombing}

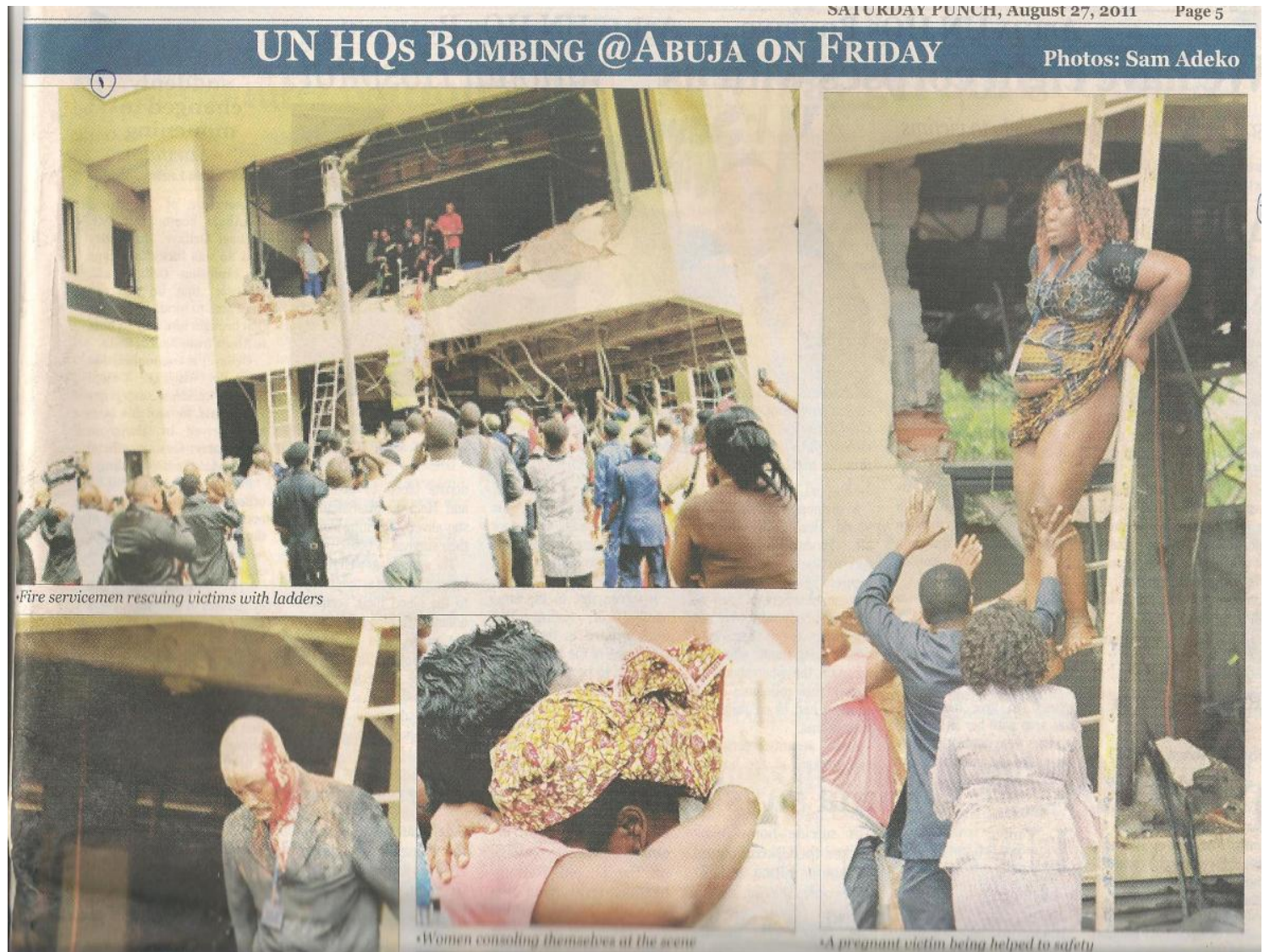

\section{Implications to National Development}

The challenges of internally displaced persons, either overtly or covertly has a tremendous implication towards nation development. The gravity of recent violent disruption and destruction of lives and properties being perpetrated by the Boko Haram attacks, and considering the fact that development as a discourse in sociological realm is multifaceted in dimensions, it can therefore be viewed from economic, social, political, educational, health and in fact, all aspect of human endeavour. The challenges of internally displaced persons are retrogressive, inimical to development.

Juxtaposing the construct "development" with the values guiding the UN Millennium Declaration and Millennium Development goals.

As articulated in the millennium declaration, the millennium development goals are benchmark for progress towards a vision of development, peace and human rights, guided by "certain fundamental values...essential to international relations in the twenty-first century. These include: 
- Freedom: Men and Women have the right to live their lives and raise their children in dignity, free from hunger and from the fear of violence, oppression or injustice. Democratic and participatory governance based on the will of the people best assures these rights.

- Equality: No individual and no nation must be denied the opportunity to benefit from development. The equal rights and opportunities of women and men must be assured.

- Solidarity: Global challenges must be managed in a way that distributes the costs and burdens fairly in accordance with basic principles of equity and social justice. Those who suffer or who benefit least deserve help from those who benefit most.

- Tolerance: Human beings must respect one another, in all their diversity of belief, culture and language. Differences within and between societies should be neither feared nor repressed, but cherished as a precious asset of humanity. A culture of peace and dialogue among all civilizations should be actively promoted.

- Respect for Nature: Prudence must be shown in the management of all living species and natural resources, in accordance with the percepts of sustainable development. Only in this way can the immeasurable riches provided to us by nature be preserved and passed on to our descendants. The current unsustainable patterns of production and consumption must be change in the interest of our future welfare and that of our descendants

- Shared Responsibility: Responsibility for managing worldwide economic and social development, as well as threats to international peace and security must be shared among the nations of the world and should be exercised multilaterally. As the most universal and most representative organization in the world, the United Nations must play the central role. (UN 2000, p.2). The above foregoing, in comprising with the wake of dynamism of plaque, internally displacement, political and social economic dwindling state of the nation (Nigeria) are pointers to the fact that the nation is still far from being on the path of stability.

\section{National Responsibility on Internal Displacement}

As noted above, addressing the problems of internal displacement is primarily the responsibility of national authorities. This requires the taking of concrete steps to prevent arbitrary displacement, protect and assist the internally displaced populations and find durable solution to their plight. To assist government with these challenging tasks, a framework developed by the Bookings Institution - University of Bern project on Internal Displacement set out the benchmarks for an effective national response and identifies twelve key steps for national authorities to take in responding to internal displacement (Bookings, 2005).

These steps are:

1. Prevention: Government has responsibility to try to prevent overt conditions on their territory that might compel population to flee. In particular, early warning and quick national response to likely phenomenon of distability to minimize its adverse effects 
provide for the safety and well-being of those affected, and to ensures that displacement last no longer than absolutely required by the circumstances.

2. Raising national awareness for the problem. The basic foundation for an effective national response is government recognition of the problems and of its responsibility to address it. For example, public pronouncements about the problems are important to build national consensus around the issue and promote solidarity with the displaced.

3. Data collection. Credible information is needed on the numbers, location and conditions of IDPs in order to design effective policies and programmes. Data should be disaggregated by age, gender and other key indicators so that the specific needs of particular groups are taken into account. Attention must also be given to whether IDPs are uprooted by armed conflict and violence or by natural disaster or by development projects. Information is needed not only on emergency situations but also on protracted situations of displacement, which often are neglected and forgotten.

4. Training. Training programmes for government officials, including camp administrators, military and police in the Guiding Principle on internal displacement is essential for ensuring that they are aware of the rights and needs of the displaced and their own official duties to protect and assist them.

5. National Legal Framework. States have been encouraged by the United Nations resolutions to develop laws to uphold the rights of IDPs, taking into account the Guiding Principles. A growing number of governments around the world have been adopting new laws or revising existing legislation.

6. A National Policy or Plan of Action. A national policy can complement national legislation. For example, it should spell out national and local institutional roles and responsibility for responding to internal displacement as well as identify the mechanism for coordination. The policy should extend to all relevant branches of government - national, local, military and police - and also to non-state actors who also must be held accountable. To be most effective, the policy should be developed in full consultation with civil society and IDPs communities and disseminated to IDPs in their own language and in form they can easily understand.

7. Creation of a Nation Institution Focal Point. This could mean assigning responsibility to internal displacement to an existing government agency, creating new body or establishing an internal departmental task force or committee.

8. A Role for National Human Rights Institutions. The role of NHRIs in reinforcing national responsibility can be important, in particular by working with governments to adopt and implement policies and laws that respect the rights of IDPs as well as investigating reports of violation of the rights and providing training programmes on the rights.

9. Participation of IDPs in Decision Making. Engaging displaced persons in consultation and building upon their skills is something often overlooked but critical to an effective response, whether the issue is relocation or design of assistance programmes or returns. The participation of women can reduce their vulnerability to sexual extortion and violence. 
10. Supporting durable solutions. Governments have a duty to establish conditions to allow IDPs to return voluntarily, in safety and dignity, to their places of habitual residence or, if they choose, to resettle in another parts of the country, and to assist IDPs to recover property and possession or obtain compensation or reparation. Decisions on when displacement ends must be taken on the basis of humane criteria ensuring respect for the full range of human rights of the displaced.

11. Allocation of Adequate Resources: National responsibility means that governments devote, to the extent they can, resources to address situations of internal displacement.

12. Cooperation with International and Regional Organizations. When governments do into have the capacity to provide for their displaced populations, they are expected to invite or accept international assistance. Indeed, cooperating with, and giving safe and unimpeded access to international agencies is a sign of responsible sovereignty.

\section{Conclusion}

Internal Displacement remains a pressing issue in the ECOWAS region. While some significant displacement crises have attenuated due to the cessation of hostilities and tens of thousands of IDPs have been able to return to their original place of residence, over a million more in the region remain in a precarious situation and new situations of internal displacement continues to occurs. A great deal therefore remains to be done to address IDPs protection and assistance needs, to find durable solutions to their plight and to prevent further displacement from taken place.

These are challenges for national and local authorities, first and foremost, to address together with the affected populations. But internal displacement also is a problem of particular impact at the regional level and one that regional bodies as well as the international community can help to address, in particular by promoting and reinforcing national efforts. Indeed, given the magnitude and complexity of crises of internal displacement, working in partnership with regional bodies and the international community may prove valuable to ensuring effective responses. The interplay of prompt intervention, constructive vibrant institutions embedded in the value of good governance, social-welfare and functional institutions engendering nation building and true dividends of democratic governance for the people should be ensued.

Also, the government should address the root causes of displaced persons and internal conflicts by taking appropriate measures with respect to the resolution of conflict, the promotion of peace and reconciliation, respect for human rights.

It is in this context that this paper is adjudged valid, given the empirical instance of poverty, inequality, unprecedented levels of bomb blast across the country and above all displacement vis-à-vis what development connotes.

\section{References}


Action Aid International, (2008). The Middle Belt in Conjuction with Internal displacement monitoring centre (IDMC), Retrieved from: Internal: http://www.internal-displacement.org

Amnesty International, (2009). Unlawful killings, Displacement, Medical care, Retrieved from: Internet:http://www.amnesty.org/en/library/asset.html

Azam, J.P. (2009). Betting on Displacement: Oil, violence, and the Switch to Civilian Rule in Nigeria.

Bookings Institution (2005). University of Bern Project on Internal Displacement: Addressing Internal Displacement: A Framework for National Responsibility.

Centre for Research on Inequality, Human Security and Ethnicity (CRISE), (2007). University of Oxford, Institutionalizing Ethnic Representation: How effective is the Federal Character Commission in Nigeria Retrieved from: Internet: http://www.crise.ox.ac.uk/pubs/working paper 43. pdf.

Deng, F.M. (1994). Internally Displaced Persons: An interim report of the UN Secretary General on protection and Assistance, New YorK: Un Dept. for Humanitarian Affairs, Washington, D.C., U.S.A,

Idowu, W. (1999). Citizenship, Alienation and Conflict in Nigeria. Retrieved from: Internet: http://ajol.info/index.php/ad/article/view/22166/19381

Integrated Regional Information Network (2010). Thousands Still homeless in Delta. Retrieved from: Internet:http://www.Internal-displacement.org.

Irobi, E. (2010). Resolving the Niger Delta confliction in Nigeria in peace Studies Journal. Vol 3, issue 1

Je'adayibe, G.D. (2008). Religions Conflicts and Internally Displaced Persons in Nigeria (in population movements, conflicts, and displacement in Nigeria, ed. T.Falola and O.Ochayi Okpeh, Jr).

Jega, A. (2000). The State and Identity Transformation under structural Adjustment in Nigeria in "Identity transformation and identity politics under structural adjustment in Nigeria" $\operatorname{chp} 2$

Kaliv, W. (2006). Opening Speech, $1^{\text {st }}$ Regional Conference on IDPs in West Africa, ECOWAS secretariat, Abuja, Nigeria, ECOWAS, UNHCR and Brookings Institution, Washington D.C., USA, p.1.

Kogi, A. (2005). In Larger Freedom: Towards Development, Security and Human Rights for All, Un doc. a/59/2005, Para.210.

Ladan, M.T. (2001). Introduction to International Human Rights and Humanitarian Laws, A.B.U Press, Zaria, Nigeria p.252

Ladan, M.T. (2006). Migration, Trafficking, Human Rights and Refugees Under International Law: A case study of Africa, Ahmadu Bello University Press, Zaria, Nigeria p9. 1-6 and 250

Ocha, T. (2003). Guiding Principles on Internally Displacement, $2^{\text {nd }}$ ed., UN., New York, USA

Okpanachi, E. (2010). Ethno-religious identity and conflict in Nigeria: Understanding the Dynamics of Sharia in Kaduna and Kebbi States. Retrieved from: Internet: http://www.ifra-nigeria.org/spip.phpanticls/107 


\section{Macrothink}

Journal of Sociological Research

ISSN 1948-5468

2013, Vol. 4, No. 1

Okpeh, O.O. (2008). Inter-group Migrations, Conflicts and Displacement in central Nigeria (in Population Movements, Conflicts, and Displacement in Nigeria, (ed.) T. Falola and O. Ochayi Okpeh, Jr)

Onijala, M.S. (2006). Welcome speech, $1^{\text {st }}$ Regional Conference on IDPs in West Africa, ECOWAS secretariat, Abuja, Nigeria Supra note 12, p.1

Reuters, A. (2009). Civilian Displaced in Nigeria, Delta Camp raids. Retrieved from: Internet: http://af.reuters.com/article/topNews/idAFJOE6B20GO20101203

The Punch, (2011). "102 die in Ibadan floods"-Red Cross; The Nigerian tabloid, vol. 17, pg. 8.

The punch, (2011). "18 killed in Abuja UN bombing” The Nigerian tabloid, vol. 7086, pg. 2. U.N, (2004). Guiding Principles on Internally Displacement, $2^{\text {nd }}$ (ed.), UN, New York, USA

\section{Biographical Notes}

Adebayo O. Fadeyi is an associate professor in the Department of Sociology, Lagos State University, Ojo, Lagos State, Nigeria. Tel: +234(0)8062331394. e-mail: fadeyi2@ yahoo.com

Tajudeen A. Oduwole is a lecturer in the Department of Sociology, currently the Head of Department, Houdegbe North American University, Route de Porto - Novo, Cotonou, Republique du Benin. His research interest includes administrative reforms, public policy analysis, development administration and sustainable governance. He is equally a $\mathrm{PhD}$ student in the Department of Sociology, Lagos State University, Ojo, Lagos State, Nigeria. Tel: +234(0)8037140814, (0)8074000361 and +229(67086446). e-mail: toduwole1@yahoo.com 